TRILOGI: Jurnal Penelitian Ilmu Sosial dan Eksakta Volume: 1, Nomor 1, 2021， Hal: 1-7

\title{
Peran Guru Pendidikan Agama Islam Dalam Membentuk Kepribadian Siswa di SMP Negeri 1 Pakem Bondowoso
}

\author{
Nanik Susilawati ${ }^{*}$, Akhmadi $^{1}$, Dhian Wahana Putra ${ }^{2}$ \\ 1Sekolah Tinggi Agama Islam At-Taqwa Bondowoso; nanik210514@gmail.com, akhmadi86@gmail.com \\ 2Universitas Muhammadiyah Jember; dhianwahana@unmuhjember.ac.id
}

\begin{abstract}
Abstrak: Pendidikan merupakan amanat yang harus dikenalkan dari generasi ke generasi berikutnya. Oleh karena itu untuk tercapainya tujuan pendidikan dan pengajaran, peran guru sangat menentukan sehingga guru menjadi salah satu faktor yang paling menentukan berhasilnya proses pembelajaran. Guru juga mempunyai peran yang sangat urgen yaitu untuk mengarahkan dan membentuk perilaku atau kepribadian anak didiknya, baik didalam sekolah maupun diluar sekolah. Penelitian ini bertujuan untuk: Mengetahui Peran Guru Pendidikan Agama Islam sebagai pembimbing, motifator dan faktor pendukung serta penghambat dalam membentuk kepribadian siswa di SMP

DOI: https://doi.org/10.47134/trilogi.v1i1.2

${ }^{*}$ Correspondensi: Nanik Susilawati

Email: nanik210514@gmail.com

Received: 20 Mei 2021

Accepted: 15 Juni 2021

Published: 30 September 2021

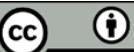

Copyright: (ㄷ 2021 by the authors. Submitted for possible open access publication under the terms and conditions of the Creative Commons Attribution (CC BY) license (http://creativecommons.org/licenses/by/4.0/).

Negeri 1 pakem Bondowoso. Metode yang digunakan adalah dengan pendekatan kualitatif yang menghasilkan data naturalistik berupa penjelasan yang bersifat alamiah. Metode pengumpulan data menggunakan observasi, interview, dan dokumentasi. Sedangkan metode analisisnya menggunakan metode analisis deskriptif dan reflektif thinking. Kemudian data yang telah terkumpul tersebut dianalisis melalui empat langkah yaitu pengumpulan data, reduksi data, penyajian data, membuat kesimpulan (verifikasi). Dan uji keabsahan data menggunakan teknik Trianggulasi. Hasil penelitian ini menunjukkan bahwa peran guru PAI sebagai pembimbing dan motivator dalam membentuk kepribadian siswa di SMP Negeri 1 Pakem sudah memberikan pencegahan dengan cara mengoptimalkan kegiatan agama untuk memberikan kegiatan positif diharapkan dengan pengetahuan tentang keilmuan PAI serta intensitas beribadah dapat tercermin dalam kehidupan sehari-hari. Sedangkan untuk mengatasi siswa yang terlanjur bermasalah, dengan di bantu guru BK dilakukan pendekatan khusus untuk diberikan binaan rohani dan bimbingan konseling...
\end{abstract}

Keywords: Peran; Pendidikan; Kepribadian

Abstrak: Education is a mandate that must be known from generation to generation. Therefore, to achieve the goals of education and teaching, the role of the teacher is very decisive so that the teacher is one of the most decisive factors for the success of the learning process. Teachers also have a very urgent role, namely to direct and shape the behavior or personality of their students, both inside and outside school. This study aims to: Determine the role of Islamic Religious Education Teachers as mentors, motivators, and supporting and inhibiting factors in shaping the personality of students at SMP Negeri 1 Pakem Bondowoso. The method used is an approach that produces data naturally in the form of natural explanations. Methods of data collection using observation, interviews, and documentation. While the method of analysis using descriptive analysis methods and reflective thinking. Then the data that has been collected is analyzed through four steps, namely data collection, data reduction, data presentation, and making conclusions (verification). And test the validity of the data using the Triangulation technique. The results of this study indicate that the role of PAI teachers as mentors and motivators in shaping the personality of students at SMP Negeri 1 Pakem has provided prevention by optimizing religious activities to provide positive activities that are expected with knowledge about PAI knowledge and worship can help in daily life. . Meanwhile, to overcome students who are already in trouble, with the help of the BK teacher, a special approach is carried out to be given spiritual guidance and counseling guidance.

Keywords: Role; Education; personality 


\section{Pendahuluan}

Pendidikan saat ini merupakan kebutuhan primer setiap manusia. Oleh karena itu, pendidikan tidak boleh dianggap sepele karena pendidikan akan meningkatkan harkat dan martabat manusia itu sendiri.

Menurut (Daradjat, 1995) "Pendidikan merupakan usaha sadar yang dilakukan oleh manusia melalui kegiatan bimbingan, pembelajaran, dan latihan, yang berlangsung di sekolah dan di luar sekolah. Pendidikan akan sempurna apabila dibarengi dengan pendidikan agama."

Pendidikan agama dalam hal ini adalah pendidikan Islam. Mohammad Fadil Al Djamaly mengatakan bahwa pendidikan islam adalah proses yang mengarahkan manusia kepada kehidupan yang baik dan mengangkat derajat kemanusiaannya, sesuai dengan kemampuan dasar (fitrah) dan kemampuan ajarnya (pengaruh dari luar). (Tohirin, 2005).

Dalam Peraturan Pemerintah Nomor 19 Tahun 2005 pasal 28, menjelaskan bahwa kepribadian adalah "kemampuan kepribadian yang mantap, stabil, dewasa, arif, dan berwibawa, menjadi teladan bagi peserta didik, dan berakhlak mulia". Masalah kepribadian juga dijelaskan didalam Al-Qur'an surat Ali Imran ayat 159 Allah SWT berfirman :

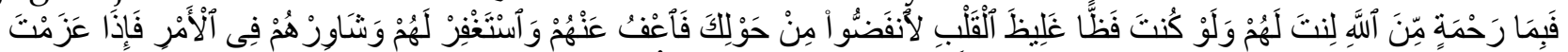

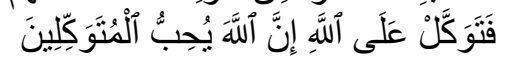

Artinya : "Maka disebabkan rahmat dari Allah-lah kamu berlaku lemah lembut terhadap mereka. Sekiranya kamu bersikap keras lagi berhati kasar, tentulah mereka menjauhkan diri dari sekelilingmu. Karena itu maafkanlah mereka, mohonkanlah ampun bagi mereka, dan bermusyawarahlah dengan mereka dalam urusan itu. Kemudian apabila kamu telah membulatkan tekad, maka bertawakalah kepada Allah. Sesungguhnya Allah menyukai orang-orang yang bertawakal kepada-Nya".

Pada dasarnya kepribadian bukan terjadi secara serta merta, akan tetapi terbentuknya melalui proses kehidupan yang panjang. Oleh karena itu banyak faktor yang ikut ambil bagian dalam upaya membentuk kepribadian tersebut, seperti faktor lingkungan keluarga, lingkungan masyarakat dan juga lingkungan sekolah. Di lingkungan keluarga dan masyarakat saja tidak cukup untuk membentuk pribadi siswa/anak, karena sebagian kegiatan anak dalam kesehariannya banyak dihabiskan dilingkungan sekolah. Di lingkungan sekolah guru sebagai pendidik bagi anak memiliki tugas yang amat besar sekali terhadap perkembangan kepribadiannya, guru sebagai pendidik utama dan juga suri tauladan bagi siswanya.

Guru memegang peran yang sangat penting dan strategis sebab ia bertanggung jawab mengarahkan anak didiknya dalam hal penguasaan ilmu dan penerapannya dalam kehidupan dan dalam menanamkan dan memberikan tauladan yang baik terhadap anak didiknya kaitanya. Seorang guru tidak hanya bertugas untuk mentransfer ilmu pengetahuan semata, tetapi jauh lebih berat yaitu untuk mengarahkan dan membentuk perilaku atau kepribadian anak didik sehingga mereka yakini terlebih guru Pendidikan Agama Islam. 
Teladan kepribadian dan kewibawaan yang dimiliki oleh guru akan mempengaruhi positif atau negatifnya pembentukan kepribadian dan watak anak. Hal ini sesuai dengan firman Allah SWT.

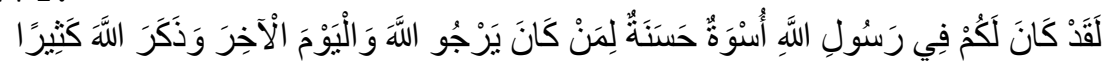

Artinya : Sesungguhnya telah ada pada (diri) Rasulullah itu suri teladan yang baik bagimu (yaitu) bagi orang yang mengharap (rahmat) Allah dan (kedatangan) hari kiamat dan Dia banyak menyebut Allah.(Q.S. AL-Ahzab :21)

Dalam ayat ini dijelaskan bahwa Rasulullah adalah suri tauladan, oleh karena itu guru dituntut memiliki kepribadian yang baik seperti apa yang ada pada diri Rasulullah SAW. Di SMP Negeri 1 Pakem bidang studi pendidikan Agama Islam ini dilaksanakan supaya lebih menambah dan mengembangkan ilmu pengetahuan siswa-siswi dalam mempelajari ilmu-ilmu agama yang dirasakan sedikit sekali pembelajaran pendidikan agama, apalagi mayoritas siswa yang ada di SMP Negeri 1 Pakem ini berlatar belakang dari sekolah umum. Oleh sebab itu pembelajaran tentang Agama Islam perlu dibenahi dan digalakkan lagi disekolah karena banyak sekali problem yang di hadapi Guru Pendidikan Agama Islam khususnya dalam membentuk kepribadian siswa.

Adapun masalah-masalah siswa yang ada SMP Negeri 1 Pakem yaitu siswanya kurang memiliki tanggung jawab sebagai pelajar, sopan santun, cara bersikap, tidak sopan pada guru dan sesama teman perilaku lemah lembut semakin jauh dari perilaku keseharian mereka dan Pemahaman ilmu Agama yang masih kurang.

Untuk memecahkan semua itu tentu tidak mudah, maka terlebih dahulu perlu diperhatikan oleh setiap pendidik bahwa dalam kegiatan belajar mengajar harus memperhatikan faktor yang mempengaruhi kepribadian anak. Melihat beberapa masalah yang ada di SMP Negeri 1 Pakem, penulis merasa tertarik untuk Mengetahui Peran Guru Pendidikan Agama Islam sebagai pembimbing, motifator dan faktor pendukung serta penghambat dalam membentuk kepribadian siswa di SMP Negeri 1 pakem Bondowoso.

\section{Metode}

Metode yang digunakan adalah dengan pendekatan kualitatif yang menghasilkan data naturalistik berupa penjelasan yang bersifat alamiah, subyek dalam penelitian ini adalah: kepala sekolah, guru pendidikan adama islam dan siswa.

Metode pengumpulan data menggunakan observasi, interview, dan dokumentasi. Sedangkan metode analisisnya menggunakan metode analisis deskriptif dan reflektif thinking. Kemudian data yang telah terkumpul tersebut dianalisis melalui empat langkah yaitu pengumpulan data, reduksi data, penyajian data, membuat kesimpulan (verifikasi). Dan uji keabsahan data menggunakan teknik Trianggulasi.

\section{Hasil dan Pembahasan}

\section{Peran Guru PAI dalam Membentuk Kepribadian Siswa}

Dalam lembaga pendidikan peran guru tentunya mempunyai berbagai peran dalam menumbuhkan kualalitas peserta didik. Salah satu peranannya adalah membentuk kepribadian siswa. 
Sekolah menengah merupakan sebuah lembaga terpenting untuk memulai menumbuhkan atau menerapkan minat memperbaiki kepribadian siswa setelah sekolah dasar karena pada usia tersebut anak sudah menginjak remaja maka perlu sekali anak untuk diarakan kepada hal-hal yang baik.

Dalam membentuk kepribadian siswa di SMP Negeri 1 Pakem guru pendidikan agama Islam mempunyai peranan yang penting, meskipun dalam pelaksanaannya guru pendidikan agama Islam melibatkan seluruh pihak sekolah. Selain kerja sama dengan pihak sekolah guru pendidikan agama Islam juga bekerja sama dengan orang tua atau wali dari siswa untuk sama-sama mengawasi, mengarahkan, membina dan membimbing anaknya jika berada di rumah atau berada di luar sekolah.

Peranan guru pendidikan agama islam menurut Ramayulis merupakan upaya sadar dan terencana dalam menyiapkan peserta didik untuk mengenal, memahami, menghayati, mengimani, bertakwa dan berakhlak mulia, mengamalkan ajaran agama islam dari sumber kitab suci Al-Qur'an dan al Hadits, melalui bimbingan, pengajaran latihan, serta penggunaan pengalaman (Mahfud, 2015)

\section{Peran Guru PAI Sebagai Pembimbing dalam Membentuk Kepribadian Siswa}

Sebagai seorang guru tidak hanya mengajar, melatih, mendidik. Seorang guru juga harus membimbing anak didiknya. Seperti yang telah dikatakan pihak sekolah di SMP Negeri I Pakem berikut ini:

"Dengan kurikulum yang sekarang ini guru bukan hanya mengajar tapi juga membimbing. Bimbingannya disini menggunakan Regulasi disekolah yaitu sudah ada tata tertibnya dan di SMP Negeri 1 Pakem juga ada kegiatan pembiasaan yaitu sholat dhuha berjamaah, kepramukaan, kerja bakti dan kegiatan-kegiatan ekstra lainya itu harus berada dalam pengawasan guru."

“Guru berusaha membimbing siswa agar dapat menemukan berbagai potensi yang dimilikinya, membimbing siswa agar dapat mencapai dan melaksanakan tugas-tugas perkembangan mereka, sehingga dengan ketercapaian itu siswa akan tumbuh dan berkembang menjadi seseorang sesuai dengan minat dan bakat yang dimilikinya."

"Guru pendidikan agama Islam dalam membimbing, mengarahkan anak sesuai dengan aturan-aturan agama, ikut melatih dan membiasakan siswa dalam melakukan kegiatan-kegiatan yang bersifat wajib maupun sunnah dalam agama. Tujuannya pembentukan pribadi siswa yaitu agar siswa setelah selesai dalam pembinaan di sekolah ini diharapkan mempunyai kepribadian yang sesuai dengan norma agama, maksudnya pribadi yang taat kepada Allah, taat kepada agama, mempunyai akhlak yang baik.

"Guru sebagai pembimbing sangatlah berperan karena situasi dan komunikasi mempengaruhi pembentukan kepribadian atau tingkah laku siswa, jika siswa terbiasa berada dalam lingkungan yang kurang baik serta siswa kurang berkomunikasi dengan orang lain baik dengan para guru khususnya guru PAI ataupun dengan masyarakat maka siswa akan lebih mudah terjerumus dalam tingkah laku yang kurang baik. 
Sebagai orang tua kedua bagi siswa guru pendidikan agama Islam berperan sebagai pembimbing yang selalu membimbing dan mengarahkan siswa ke arah positif. Dalam membentuk pribadi siswa guru pendidikan agama Islam mempunyai tanggung jawab yang besar untuk menciptakan kepribadian siswa yang baik, yang sesuai dengan ajaran-ajaran agama. Bentuk bimbingan secara langsung guru Pendidikan Agama Islam SMP Negeri 1 Pakem yaitu membimbing berdoa bersama saat mulai dan selesai pelajaran, membimbing dengan memberikan nasihat-nasihat kepada siswa, membimbing siswa dalam memngikuti kegiatan-kegiatan sekolah. Sedangkan untuk mengatasi siswa yang terlanjur bermasalah, yaitu dengan di bantu guru BK dilakukan pendekatan khusus untuk diberikan binaan rohani dan bimbingan konseling. Hal ini selaras dengan hasil penelitian (Arifin, 2020) Guru bimbingan dan konseling memberi bantuan, arahan, motivasi, dan bimbingan kepada siswa yang sedang mendapat masalah. Jadi bimbingan dan konseling mempunyai peran yang sangat penting dalam proses pendidikan untuk membantu mengatasi celah dan kekurangan di sekolah, supaya tujuan dan sasaran Pendidikan bisa tercapai dengan optimal.

\section{Peran Guru PAI Sebagai Motivator dalam Membentuk Kepribadian Siswa}

Setelah peneliti cermati peran guru sebagai motivator bagi guru maupun siswa yang ada di SMP Negeri I Pakem begitu penting karena guru-guru sebelum memulai pelajaran menyisikan waktu 10 atau 15 menit untuk membimbing dan memotivasi siswa karena perkembangan mental anak jaman sekarang sudah di pengaruhi oleh perkembangan teknologi sehingga anak-anak banyak yang kurang memperhatiakan sekolah. Oleh karena itu guru harus memberi motivasi supaya bisa mencetak kepribadian yang baik bagi siswa."

Guru bahkan tidak malu-malu mengabsen siswa sholat apa tidak dan itu di kerjakan setiap hari dan setiap pembelajaran, hanya kelemahannya sementara ini pelajaran agama yang hanya 2 jam yang kelas VII hanya 3 jam sehingga kita memotivasi siswa hanya sebatas didalam kelas. Guru yang lain juga membantu dalam membentuk kepribadian siswa dengan cara yang sama yaitu mengingatkan, mengabsen, menanyai siswa paling tidak bisa sholat 5 waktu dirumahnya atau dimasjidnya setiap waktu. Setiap hari semua siswa selalu dimotivasi bukan hanya sholat saja namun siswa juga diingatkan supaya menjadi penolong, membantu orang tua dirumah, akhlaknya dipakai, sopan santun baik perkataan dan perbuatannya.

Peran guru sebagai motivator begitu penting dan harus dimiliki oleh semua guru bukan hanya guru PAI saja, dalam mengajar tidak hanya cukup dengan menggunakan materi saja tapi sebagai guru kita harus tau bagaimana siswanya, karena anak didik pasti tidak semuanya gampang nerima materi dari guru, jadi motivasi dari seorang guru memeiliki peranan yang sangat penting, karena dengan motivasi tentu siswa akan mempunyai semangat belajar yang tinggi sehingga guru mudah mengatasi kesulitan-kesulitan anak dalam belajar.

Untuk seorang siswa motivasi itu sangat penting sekali, karena sepintar-pintarnya siswa jika malas-malasan atau kurang semangat maka akan mengganggu sama aktifitas 
belajarnya untuk itu diharapkan seorang guru itu bisa menjadi motivator bagi siswanya agar siswa bisa mempunyai semangat belajar yang tinggi, seperti yang telah dilakukan oleh guru PAI di SMPN I Pakem sangat memotivasi anak didiknya dengan berbagai cara apalagi disana banyak siswa yang tidak tahu tata cara bersikap kepada guru dan sesama teman padahal Akhlak itu sangat penting sekali bagi mereka namun guru PAI di SMPN I Pakem ini begitu mulia hatinya beliau sangat berharap semua siswanya bisa menjadi pribadi yang lebih baik, menurut beliau salah satu cara yang ia lakukan yaitu dengan memberi semangat serta mendorong semangat belajar anak didiknya tidak hanya itu beliau selalu memberi perhatian dan selalu telatem mengajari siswanya serta berusaha menjadi pelatih yang baik.

Selaras dengan hasil penelitian yang di lakukan oleh (Haris, 2019) Guru pendidikan agama islam sebagai pengajar memberikan ilmu yang sesuai dengan skill yang dimilikinya, melakukan pembentukan kepribadian siswa dengan cara berkomunikasi dengan siswa, berinteraksi dengan siswa. Memberikan pengalamanpengalaman yang baik, seperti menjadi tauladan, mencontohkan perilaku baik, bertutur bahasa yang halus. Serta, seorang guru berperan mengatur kegiatan yang dilakukan oleh siswa, dengan melakukan pengawaasan-pengawasan lingkungan siswa, seperti mengawal kegiatan sholat berjamaah, dll.

\section{Faktor Pendukung dan Penghambat dalam Membentuk Kepribadian Siswa}

Dengan semakin berkembangnya ilmu pengetahuan saat ini, menjadi faktor pendorong dan penghambat upaya pembaharuan dalam dunia pendidikan. Berbagai upaya untuk mencapai tujuan pendidikan Indonesia dewasa ini terus berlangsung dan berkembang.

Setelah peneliti cermati peran guru bagi guru maupun siswa yang ada di SMP Negeri I Pakem begitu penting, peneliti memperoleh hasil:

"Keadaan lingkungan siswa menjadi salah satu faktor penghambat karena kurangnya kesadaran siswa dalam melakukan kegiatan keagamaan untuk membentuk pribadi siswa sehingga harus membutuhkan kerja ekstra, kesabaran, dan ketelatenan dari guru untuk membiasakan siswa mengikuti kegiatan keagamaan. Minimnya pendidikan agama dalam keluarga dan kurangnya perhatian dari orang tua, terkadang orang tua lebih dering berada di luar rumah untuk mencari nafkah sehingga anak kurang pengawasan dari orang tua dan kurang bimbingan dari orang tua. Sedangkan faktor pendukungnya adanya kerja sama antara guru atau pihak sekolah dengan orang tua siswa untuk berbagi tugas mengawasi, membimbing, mendidik, dan membina di sekolah maupun di rumah. Adanya kebijakan-kebijakan dari sekolah seperti tata tertib, kegiatankegiatan dari sekolah yang mempengaruhi kebiasaan dan tingkah laku siswa sehingga membentuk pribadi siswa yang diharapkan."

"Faktor pendukung lainnya yaitu adanya musholla, seluruh siswa beragama islam, sekolah dekat dengan masjid. Sedangkan faktor penghambatnya pembelajaran PAI sebatas 2 jam, rata-rata orang tua siswa tidak berpendidikan, kurangnya pantauan dari orang tua, 
tidak tersedia musium pendidikan agama dan terbatasnya alat peraga keislaman sehingga saat melakukan praktek agama terkadang sulit untuk difahami oleh siswa.

Kendala yang dihadapi guru pendidikan agama islam dalam membentuk kepribadian siswa adalah lingkungan dari luar sekolah, seperti lingkungan bermain, bawaan budaya yang dari berbagai kota asal, dan faktor internal yaitu keluarga, seperti keharmonisan keluarga (Haris, 2019)

\section{Simpulan}

1. Peran guru dalam membimbing siswa yaitu dengan memberi arahan pada anak sesuai dengan atura-aturan agama, ikut melatih dan membiasakan siswa dalam melakukan kegiatan-kegiatan yang bersifat wajib maupun sunnah dalam agama.

2. Peran guru sebagai motivator mempunyai peran yang sangat penting Membentuk Kepribadian Siswa karena dengan motivasi siswa akan lebih mempunyai semangat belajar yang tinggi untuk itu para guru khususnya guru PAI begitu memotivasi, mendukung, mendorong siswanya agar menjadi pribadi yang baik.

3. Yang menjadi faktor penghambat guru Pendidikan Agama Islam dalam membentuk kepribadian siswa adalah Niat dan minat siswa, Terbatasnya waktu, Pergaulan di luar sekolah, Sarana dan prasarana yang kurang mendukung, Minimnya Pendidikan Agama dan SDM orang tua lemah, perkembangan Teknologi. Sedangkan Faktor pendukung yaitu Adanya kerja sama antara guru dan orang tua dalam mengawasi, mendidik dan membina siswa, Lingkungan sekolah yang masih kental dengan kegiatan keagamaan, Kegiatan-kegiatan yang ada di sekolah dan adanya tata tertib di sekolah.

\section{Daftar Pustaka}

Arifin, A. (2020). Peran Guru Bimbingan Konseling Dalam Membentuk Kepribadian Siswa di Madrasah Tsanawiyah Nurul Falah Kayu Tinggi Cakung Jakarta Timur. Jurnal Alasma: Media Informasi dan Komunikasi Ilmiah, 2(1), 101-122.

Daradjat, Z. (1995). Pendidikan Islam dalam keluarga dan sekolah. Ruhama.

Haris, L., Hanif, M., \& Hasan, N. (2019). Peran Guru Pendidikan Agama Islam dalam Membentuk Kepribadian Siswa di Madrasah Aliyah Negeri 1 Kota Malang. Vicratina: Jurnal Pendidikan Islam, 4(4), 155-161.

Mahfud, M. (2015). Peran Guru PAI dalam Meningkatkan Motivasi Belajar Peserta Didik di SD Negeri Wonokerto 01 Kecamatan Bandar Kabupaten Batang (Doctoral dissertation, STAIN Pekalongan).

Pemerintah, P. (2005). Peraturan Pemerintah Republik Indonesia nomor 19 tahun 2005 tentang standar nasional pendidikan. Departemen Pendidikan Nasional Republik Indonesia.

Tohirin, M. (2005). Pendidikan Agama Islam. 